\begin{tabular}{|l|l|l|l|l|l|}
\hline J. Tek. Ling & Vol. 10 & No. 2 & Hal. 183 - 193 & Jakarta, Mei 2009 & ISSN 1441-318X \\
\hline
\end{tabular}

\title{
PEMBENTUKAN TUNAS Lilium sp. SECARA EX VITRO DAN IN VITRO
}

\author{
Djadja Siti Hazar Hoesen \\ Peneliti di Pusat Penelitian Biologi \\ Lembaga IImu Pengetahuan Indonesia
}

\begin{abstract}
Buds, planlets and bulblets formation from excised bulbscales was the preferred method for vegetative propagation of Lilium sp (Liliaceae). The ex vitro techniques with Gibberellic acid (GA3) pretreatment was induced buds formation on scales cutting which planted on sterilized sand media. Buds rised from basal scales 7 days after planted. However scales untreated GA3 obtained in 35-42 after planted. In vitro methods to promote buds initiated from bulbscales explants, was induced on media MS (Murashige and Skoog) supplemented with GA3 $1 \mathrm{mg} / \mathrm{l}$. Media for induced buds formation, MS contained Benzyl adenine (BA) $1 \mathrm{mg} / \mathrm{l}$ and $2 \mathrm{mg} / \mathrm{l}$ increased multiple shoots formation significantly compared cultured on media without BA. Roots growth improved on media contained NAA, but the highest planlets achieved on cultured MS media without BA. Bulblets formation obtained on media contained higher concentration of $B A(5 \mathrm{mg} / \mathrm{l})$.
\end{abstract}

Key words: bulbscale, bulblet, Lilium sp., ex vitro, in vitro, propagation.

\section{PENDAHULUAN}

\subsection{Latar Belakang}

Lilium merupakan salah satu marga/ genus dari suku/famili Liliaceae. Suku ini memiliki lebih dari 240 marga lebih dari 3000 jenis/spesies. Merupakan herba berumbi, perennial, berasal dari daerah yang beriklim sedang yaitu bagian utara Eropa, Amerika Utara dan Jepang. Sebagian jenis Lilium merupakan tumbuhan asli Benua Asia, dikenal karena keindahan bunganya baik bentuk maupun warna dan berbau harum. Lilium oleh sebagian kultur masyarakat dilambangkan sebagai kesuburan dan ketenangan. Tanaman lili, berbunga hampir sepanjang tahun. Lilium sebagai bunga potong, mampu bertahan 7-14 hari dalam vas bunga. Di Indonesia tanaman tersebut dipelihara sebagai tanaman hias pengisi taman, sebagai tanaman border dan penghias pagar atau sebagai bunga potong dan rangkaian bunga di dalam ruangan yang dikombinasikan dengan bunga lainnya. Menurut ahli biologi, bunga ini dapat menimbulkan kesan yang ramah, menandakan persahabatan sejati (http://www.floridata.com/ref/L/lili hyb. cfm; wikipedia.org/wiki/Bunga Lili) ${ }^{1)}$. Selain sebagai tanaman hias, umbi lili mengandung glukomannan (Wozniewski, 1991)2) bahkan pernah dilaporkan berkhasiat obat sebagai antitusif (batuk) dan sedatif (penenang) (http://www.republika.co.id) ${ }^{3)}$. Di daerah pegunungan pulau Jawa, sejumlah jenis lili telah dibudidayakan sebagai tanaman hias pekarangan sejak lama. Lili umumnya dapat tumbuh baik di tempat yang mendapat sinar matahari 5-6 jam/hari di tempat yang agak ternaungi, namun sebagian jenis Lilium dapat tumbuh subur di tempat terbuka dengan sinar matahari penuh a.I. L. candidum, L. croceum, L. elegans, 
L. martagon, L. monadelphum dan L. triginum. Sementara suhu lingkungan yang dikehendaki untuk pertumbuhannya yaitu di daerah yang malam hari bersuhu $4,5-10^{\circ} \mathrm{C}$ dan siang $20^{\circ} \mathrm{C}$. Perbanyakakan lili secara konvensional dapat dilakukan baik secara generatif maupun vegetatif5). Pembudidaya tanaman lili di daerah Lembang mendapatkan masalah adanya masa istirahat/dormansi umbi (komunikasi pribadi).

Cara perbanyakan vegetatif dengan umbi dan sisik umbi dengan teknik in vitro, dapat menyediakan bibit secara massal. Perbanyakan dengan teknik kultur jaringan menggunakan eksplan sisik umbi tersebut telah dilakukan ${ }^{5}$. Selanjutnya, perbanyakan dengan teknik yang hampir sama juga telah dilakukan ${ }^{6}$. Budidaya in vitro tersebut selain menghasilkan bibit dalam jumlah banyak, juga dapat dapat menghasilkan tanaman yang bebas dari penyakit ${ }^{7)}$; http:// suhudoedin.blogspot.com/2008/08/kulturjaringan-lyly.html) $^{8)}$.

Lili mempunyai nilai ekonomi yang tinggi11). Untuk tujuan komersial, pengaplikasian teknik perbanyakan massal secara in vitro sangat memungkinkan karena akan menyediakan bahan tanaman/bibit secara terus menerus, mengingat tanaman tersebut mengalami masa istirahat/dormansi ${ }^{10}$ ). Di Indonesia sendiri tanaman lili relatif kurang populer, padahal pengembangan budidayanya dapat dilakukan sebagai tanaman sela di antara tanaman perkebunan ${ }^{11)}$. Kelompok peneliti tanaman hias khususnya lili, telah menghasilkan varitas unggul baru skala laboratorium yang dapat beradaptasi dalam kondisi daerah tropis ${ }^{9)}$.

Perlakuan ZPT giberrelin dapat menginduksi perpanjangan buku/'internode' dan pertumbuhan jaringan meristem, memperpendek atau bahkan menghentikan masa dormansi umbi lili secara konvensional (ex vitro) dan nonkonvensional (in vitro). Sitokinin, dapat menstimulasi pertumbuhan dan perkembangan eksplan secara in vitro, apabila dikombinasikan dengan auksin dapat mendorong pembelahan sel. Pembentukan planlet dan bulblet lili secara in vitro dipengaruhi oleh adanya zat pengatur tumbuh tersebut dalam media.

\subsection{Tujuan Penelitian}

Penelitian ini bertujuan untuk mempercepat pembentukan tunas secara ex vitro dan in vitro dengan pengaplikasian asam giberelat (GA3) dan menentukan formulasi media yang berhasil menginduksi pembentukan tunas/planlet dan bulblet secara in vitro dengan perlakuan zat pengatur tumbuh auksin dan sitokinin.

\section{METODOLOGI PENELITIAN}

\subsection{Bahan}

Bahan eksplan berupa sisik umbi/ scale Lilium sp. diperoleh dari pembudidaya tanaman lili di daerah Lembang Bandung ketinggian tempat sekitar $800 \mathrm{~m}$ dpl. Bahan kimia unsur makro dan mikro media formulasi Murashige dan Skoog dan phytagel.

\subsection{Peralatan}

Alat yang digunakan pada proses penanaman secara konvensional dan in vitro antara lain adalah pinset, scalpel, pisau, bak persemaian, laminar air flow cabinet untuk penanaman secara aseptis, autoclave untuk sterilisasi media dan peralatan, $\mathrm{pH}$ meter dan peralatan laboratorium lainnya.

\subsection{Waktu dan Tempat Penelitian}

Penelitian ini dilakukan di laboratorium Treub (Laboratorium Fisiologi Tumbuhan dan Kultur Jaringan) Bidang Botani Puslit Biologi-LIPI, pada tahun 2006-2007. 


\subsection{Metode Penelitian}

\subsubsection{Penanaman dalam media pasir}

Umbi lili terdiri dari lapisan sisik, umbi lapis tersebut dicuci dan dibersihkan dari kotoran yang melekat, kemudian sisik bagian yang paling luar hingga lapis ke tiga dikupas, sisik/scale tersebut sebagian direndam dalam larutan GA3 10 mg/l selama 16 jam dalam suhu lemari es $\left(8-9^{\circ} \mathrm{C}\right)$; yang lainnya (kontrol) langsung ditanam dalam bak plastik yang telah berisi media pasir steril. Setiap bak pembibitan terdiri dari 50 buah sisik dan setiap perlakuan diulang 3 kali. Media tanam harus dipelihara agar tetap lembab. Penanaman dalam media pasir tersebut harus dijaga kelembaban medianya, karena apabila terlalu basah akan membusuk. Untuk menghindari hal tersebut, bak persemaian ditutup dengan plastik transparan dan ditempatkan di rumah kaca yang dilengkapi blower/kipas. Pengamatan dilakukan terhadap persen sisik umbi yang berhasil membentuk bakal tunas dan saat munculnya bakal tunas (minggu setelah tanam).

\subsubsection{Kultur in vitro}

Umbi lapis yang berisi sisik bagian dalam yang telah dicuci dengan air mengalir, kemudian disterilkan dengan larutan klorox 20-30\% selama 20 menit, dibilas air suling steril 3-4 kali. Umbi yang telah disterilkan tersebut, dikupas bagian Iapisan yang telah menyerap larutan klorox hingga umbi berukuran diameter 0,5-0,8 cm, kemudian dibelah menjadi empat bagian secara vertikal, pengerjaan tersebut dilakukan secara aseptis dalam Laminar Air Flow Cabinet. Setelah dikultur sekitar 1 minggu dari saat penanaman, sisik umbi telah terbuka dari lapisannya dan sisik tersebut yang digunakan sebagai bahan eksplan (steril) untuk penelitian kultur in vitro. Penelitian terdiri dari beberapa tahapan: Tahap inisiasi, untuk mendapatkan kultur yang bebas dari kontaminasi mikroorganisme dan mempercepat pembentukan bakal tunas. Perlakuan percobaan adalah penambahan $1 \mathrm{mg} / \mathrm{l}$ GA3, $1 \mathrm{mg} / \mathrm{l}$ BA dan kontrol (media dasar MS tanpa ZPT). Penelitian disusun secara rancangan acak lengkap (RAL) dengan 10 ulangan (masing-masing perlakuan 50 eksplan). Pengamatan pada tahap tersebut adalah saat muncul dan jumlah bakal tunas. Tahap berikutnya adalah tahap perbanyakan untuk menginduksi pembentukan tunas/ anakan, yaitu setelah kultur berumur 6 minggu dari saat subkultur pada media dasar yang ditambah BA 1 mg/l, BA 2 mg/l dan kontrol. Subkultur kedua dilakukan setelah 8 minggu dari subkultur pertama pada media dasar yang ditambah BA 5 $\mathrm{mg} / \mathrm{l}$. Sementara subkultur ketiga dilakukan setelah 4 minggu dari saat subkultur kedua, percobaan tersebut untuk menginduksi pembentukan dan pembesaran planlet, serta pembentukan akar. Perlakuan pada tahapan tersebut yaitu penambahan $1 \mathrm{mg} / \mathrm{l}$ BA, 1 mg/l BA + 0,5 mg/l NAA; 0,5 mg/l NAA dan kontrol. Parameter yang diamati pada tahap perbanyakan adalah jumlah tunas, jumlah daun, jumlah akar dan tinggi planlet. Tahap pembesaran planlet dari tunas yang ukuran morfologinya belum proporsional dan untuk menginduksi perakaran, yaitu $\mathrm{MS}+0,1 \mathrm{mg} / \mathrm{l}$ kinetin + 0,1 $\mathrm{mg} / \mathrm{l}$ BA dan $\mathrm{MS}+0,5 \mathrm{mg} / \mathrm{l}$ NAA dan MS tanpa ZPT. Aklimatisasi dilakukan pada planlet yang berakar dengan ukuran dan morfologi tanaman yang telah proporsional (umbi telah terbentuk), media yang digunakan pada tahap aklimatisasi tersebut adalah campuran tanah, pasir dan kompos dengan perbandingan $1: 1: 2$.

\section{HASIL DAN PEMBAHASAN}

\subsection{Induksi pembentukan tunas Lilium sp. dengan perlakuan asam giberelat}

Hasil pengamatan, Pembentukan tunas dari sisik umbi yang diberi perlakuan 
perendaman GA3 10 mg/l selama 16 jam, pada minggu pertama setelah tanam, tampak $90 \%$ sisik umbi membentuk bakal tunas di bagian pangkal sisik. Sementara kontrol (eksplan yang langsung ditanam) belum menunjukkan adanya perkembangan, walaupun tampak masih segar. Bakal tunas baru muncul setelah 4-5 minggu, persentase sisik yang menghasilkan tunas 80\%-85\% (Gambar 1). Keberhasilan hidup dari tunas tersebut persentasenya relatif kecil yaitu 50-55\% yang dapat tumbuh dengan baik di luar rumah kaca, karena sebagian terserang hama kutu daun dan belalang yang menyebabkan tanaman tersebut menjadi kering dan akhirnya mati. Laporan penelitian tentang perbanyakan dengan sisik umbi berhasil memperbanyak tanaman 'Easter lily' secara ex vitro ${ }^{13}$. Peneliti lainnya melaporkan bahwa umbi lili hasil perbanyakan secara in vitro mengalami masa dorman ketika dipelihara secara ex vitro, kejadian tersebut teramati pada umbi Lilium speciosum ${ }^{12}$.
Selanjutnya Gunta et al. ${ }^{12)}$, melaporkan bahwa dormansi umbi Lilium speciosum akan terjadi pada lingkungan yang bersuhu $>15^{\circ} \mathrm{C}$ dan tidak semua jenis lili mengalami masa dorman, seperti kelompok Asia dan bunga lili tipe Trompet ('Trumpets type') dapat tumbuh secara optimal pada suhu relatif tinggi.

\subsection{Pembentukan tunas kultur sisik umbi secara in vitro}

Tahap inisiasi. Sisik umbi, terbuka dari lapisan umbi pada 4-7 hari (1 minggu) setelah penanaman (bahan eksplan), 80\%-90\% kultur bebas dari kontaminasi mikroorganisme dan berhasil hidup. Kultur dalam media yang diberi perlakuan GA 1 $\mathrm{mg} / \mathrm{l}$, setelah 1 minggu dari saat pemindahan (pemisahan sisik), tampak pada pangkal sisik telah terlihat adanya pembengkakan dan munculnya bakal tunas, sementara pada media tanpa ZPT belum menunjukkan perkembangan yang signifikan walaupun

Gambar 1. Persen pembentukan tunas sisik umbi lili dalam media pasir 1 - 5 minggu

$\%$

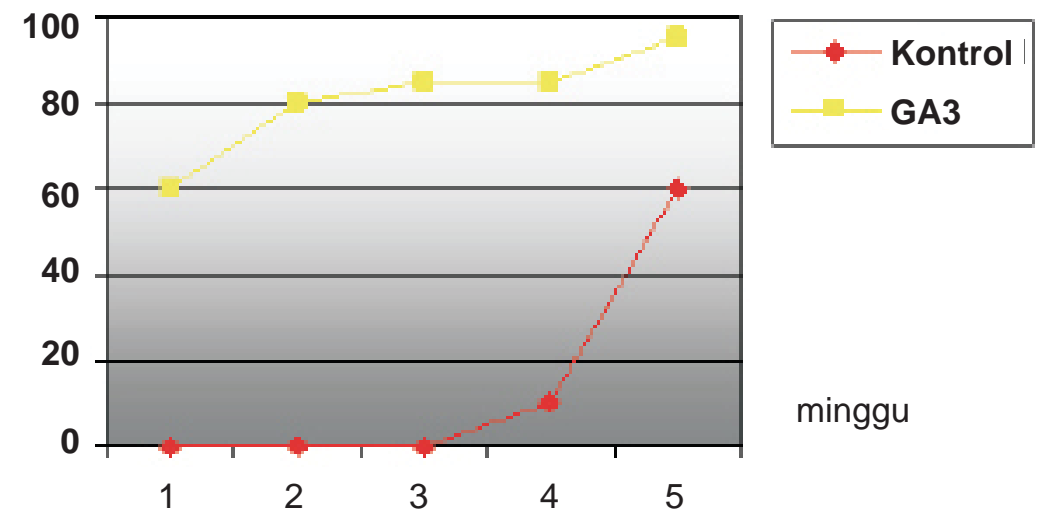

Diduga masa istirahat juga dialami oleh umbi Lilium sp. yang dicoba pada penelitian ini, terlihat bahwa saat pembentukan bakal tunas yang lebih lama dibandingkan dengan sisik yang diberi perlakuan GA3 (Gambar 1), karena GA3 salah satu hormon yang berperanan dalam proses pertumbuhan dan dapat memperpendek masa dormansi.

tampak eksplan masih segar dan tidak mengalami pencoklatan. Setelah bakal tunas tumbuh dan berkembang yaitu setelah tunas muncul, umumnya terjadi setelah 3-4 minggu dari saat inisiasi. Dari tahap inisiasi tersebut dihasilkan jumlah tunas terbanyak pada media yang mengandung $1 \mathrm{mg} / \mathrm{l}$ BA (Gambar 2). Sitokinin (BA) dan asam 
giberelat $\left(\mathrm{GA}_{3}\right)$ telah berhasil mendorong pembentukan tunas secara in vitro pada sejumlah jenis tanaman lili dan tanaman lainnya. Kultur in vitro dengan eksplan sisik umbi pada tanaman lili telah dilaporkan oleh peneliti sebelumnya; sebagian besar menggunakan bahan/material hibrida dari Asia (Asiatic hybrids), kultivar L. longiflorum dan lili tipe oriental (oriental types) ${ }^{2}$. Pengaruh $\mathrm{GA}_{3}$ terhadap pertumbuhan dan perkembangan tanaman tampak pada kultur sisik umbi Lilium sp. secara in vitro. Pembentukan tunas dipercepat oleh adanya penambahan $1 \mathrm{mg} / \mathrm{l} \mathrm{GA}$ ke dalam media MS, dalam hal ini asam giberelat berhasil mendukung proses fisiologi pada tahap inisiasi eksplan secara in vitro. Keadaan yang hampir sama, dilaporkan

Gambar 2. Pembentukan tunas kultur Lilium sp pada tahap inisiasi

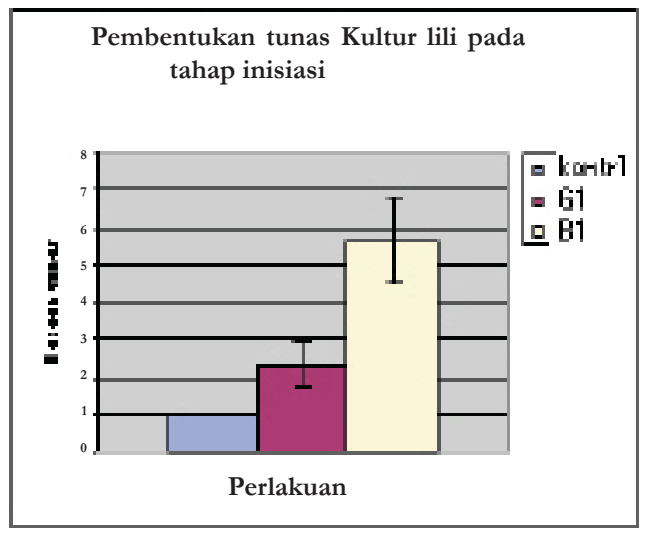

bahwa kultur eksplan nodus (ruas) dari tangkai bunga (Lilium longifflorum) untuk tujuan mikroprogpagasi, dikulturkan dalam media MS yang mengandung $1,0 \mathrm{mg} / \mathrm{l}$ asam giberelat $\left(\mathrm{GA}_{3}\right)$ dan $0,5 \mathrm{mg} / \mathrm{l} 6$ benzyladenine (BA).

Tunas berhasil terbentuk setelah 1 bulan dari saat subkultur, kemudian tunas tersebut disubkultur ke dalam media yang ditambah $0,5 \mathrm{mg} / \mathrm{l}$ BA. Nilai rataan yang diperoleh sebanyak 30 tunas yang subur dan seragam (TanNhut, 2003 http://cat. inist. fr/?aModele $=$ afficheN\&cpsidt $=14928$ 561) $^{14)}$

Tahap perbanyakan. subkultur pertama dengan cara memisahkan tunas dari sisik yaitu 4 minggu setelah saat inisiasi, kultur dalam media yang diberiperlakuan

Gambar 2. Pembentukan tunas kultur Lilium sp pada tahap inisiasi

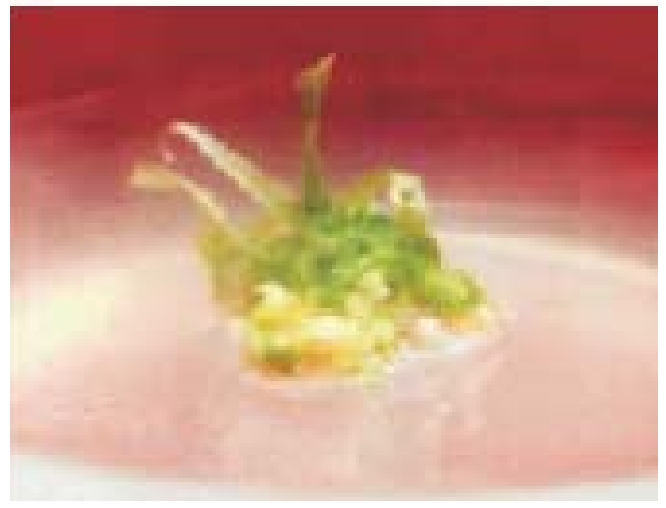

Tabel 1. Pengaruh penambahan BA terhadap pembentukan dan pertumbuhan tunas kultur Lilium sp.

\begin{tabular}{|c|c|c|c|c|}
\hline $\begin{array}{c}\text { Perlakuan } \\
\text { BA (mg/l) }\end{array}$ & $\begin{array}{c}\text { Rataan jumlah } \\
\text { tunas }\end{array}$ & $\begin{array}{c}\text { Rataan jumlah } \\
\text { daun }\end{array}$ & $\begin{array}{c}\text { Rataan jumlah } \\
\text { akar }\end{array}$ & $\begin{array}{c}\text { Rataan } \\
\text { panjang tunas } \\
(\mathrm{cm})\end{array}$ \\
\hline B0 (Kontrol) & $1,67^{\mathrm{a}}$ & $9,3051^{\mathrm{a}}$ & $8,50^{\mathrm{a}}$ & $10,03^{\mathrm{a}}$ \\
\hline B1 & $7,67^{\mathrm{b}}$ & $11,50^{\mathrm{a}}$ & $11,67^{\mathrm{a}}$ & $8,30^{\mathrm{a}}$ \\
\hline B2 & $9,00^{\mathrm{b}}$ & $18,33^{\mathrm{b}}$ & $17,00^{\mathrm{b}}$ & $7,00^{\mathrm{a}}$ \\
\hline
\end{tabular}

Keterangan : nilai rataan \pm galat baku, angka yang bertanda huruf sama satu kolom menunjukkan hasil yang tidak signifikan pada uji beda rata-rata nilai pd" $5 \%$ 
penambahan (1 dan 2) mg/l BA tampak bakal tunas yang menggerombol. Dari nilai rataan teramati adanya perkembangan yang signifikan dibandingkan dengan kontrol (tanpa BA), pada kultur dengan penambahan perlakuan $1 \mathrm{mg} / \mathrm{l}$ BA berhasil menginduksi pembentukan tunas $(7,67 \pm 0,52)$ dan meningkat lagi pada kultur yang mengandung $2 \mathrm{mg} / \mathrm{l}$ BA $(9,00 \pm 1,41)$. Sementara kultur dalam media yang tidak mengandung BA nilai rataan 'bulblet' atau

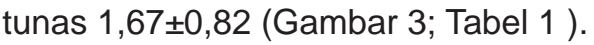

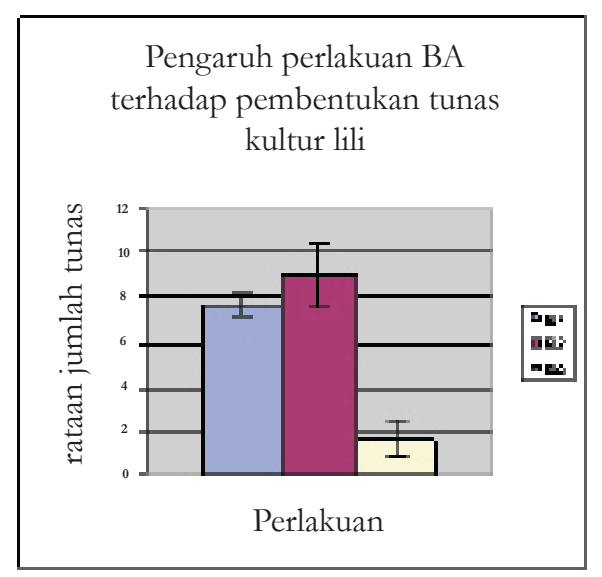

Gambar 3. Histogram pengaruh perlakuan terhadap pembentukan kultur lili

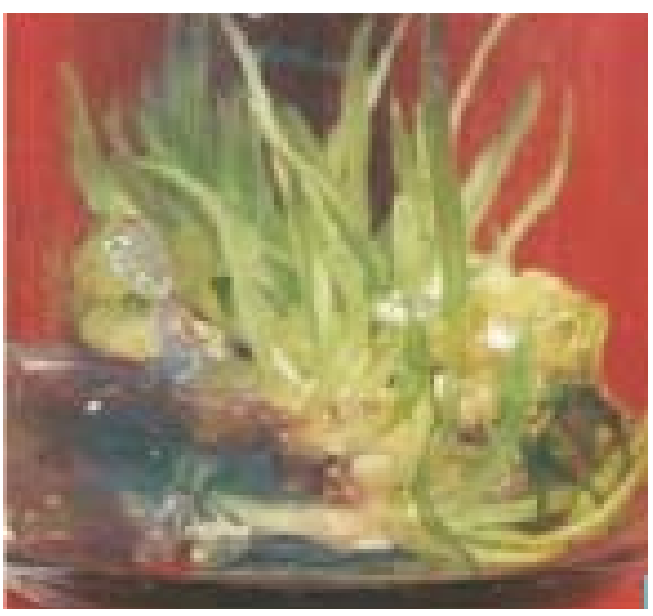

Foto 2.

Pembentukan tunas pembentukan tunas tahap perbanyakan
Nilai rataan perubah jumlah daun juga menunjukkan adanya kecenderungan meningkat seiring dengan meningkatnya konsentrasi BA. Kultur dalam media tanpa BA dapat membentuk daun 9,3 $\pm 1,51$.

Penambahan $1 \mathrm{mg} / \mathrm{l}$ BA berhasil membentuk tunas $11,50 \pm 4,23$ dan meningkat secara nyata menjadi 18,33 \pm 2,34 dalam media yang mengandung 2 mg/l BA (Gambar 4, Tabel 1).

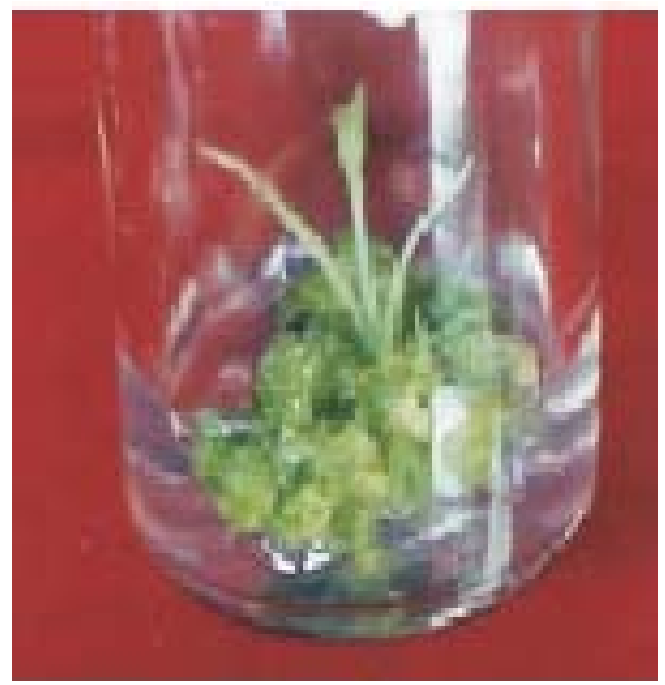

Foto 3. Pembentukan bulblet

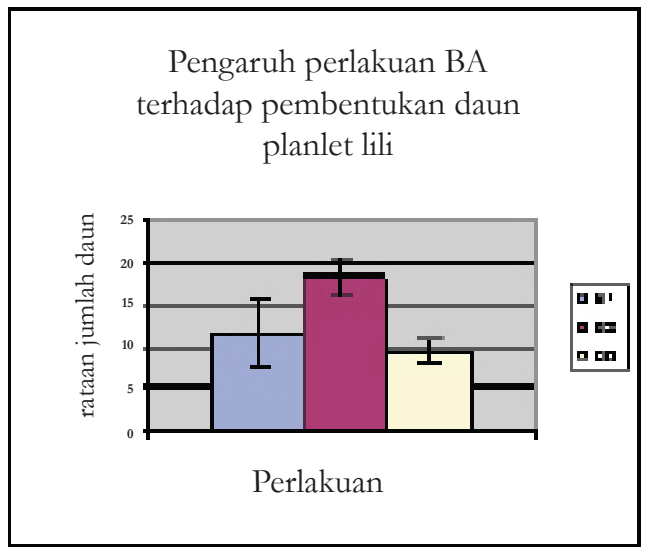

Gambar 5. Histogram pengaruh perlakuan terhadap pembentukan akar planlet lili 
Respon yang hampir sama terjadi juga pada kultur Crinum sp. (Liliaceae), penambahan $2 \mathrm{mg} / \mathrm{lBA}$ menghasilkanjumlah rataan tunas tertinggi. Sementara eksplan umbi amarilis berhasil meningkatkan jumlah tunas secara in vitro pada media yang mengandung $1 \mathrm{mg} / \mathrm{l} \mathrm{BA}{ }^{15}$. Tahap subkultur ke dua yaitu tunas/bulblet dipindahkan ke media MS yang ditambah $5 \mathrm{mg} / \mathrm{l} \mathrm{BA}$, jumlah tunas/bulblet meningkat secara tajam, tetapi ukuran masing-masing individu tunas/bulblet lebih kecil dari perlakuan lainnya, hal tersebut terjadi juga pada kultur amarillis dan Crinum sp. pada kultur dengan nilai rataan tunas tertinggi, menghasilkan individu tunas terkecil. ${ }^{4,15)}$ Hal tersebut diduga karena keterbatasan nutrisi dan oksigen atau adanya zat toksik dari hasil metabolisme eksplan selama proses pertumbuhan yang menyebabkan pertumbuhan planlet/bulblet tidak optimal.

Dari pengamatan setelah subkultur ke dua, tampak kultur memberikan respon yang positif terhadap perlakuan BA dengan konsentrasi yang lebih tinggi dibandingkan dengan perlakuan sebelumnya yaitu 5 $\mathrm{mg} / \mathrm{BA}$, pembentukan tunas dan bakal tunas mencapai 20 - 25, tetapi ukuran masing-masing individu tunasnya lebih kecil, bahkan menghasilkan bakal tunas yang menggerombol dan menghasilkan 'bulblet'.

Tahap pembesaran. Hasil dari subkultur ke tiga dari bulblet yang menggerombol (berasal dari kultur dalam media 5 mg/l BA), kultur tersebut berumur 6 minggu setelah dipindahkan ke dalam media yang mengandung $1 \mathrm{mg} / \mathrm{l} \mathrm{BA}$, menghasilkan jumlah tunas $(6,67 \pm 0,57)$ dan daun $(10,67$ $\pm 5.51)$ tertinggi; sementara $1 \mathrm{mg} / \mathrm{l} \mathrm{BA}+0,5$ mg/l NAA (B1N0,5) menghasilkan jumlah akar 16,67 $\pm 1,15$ dan 0,5 mg/l NAA $(\mathrm{N} 0,5)$ menghasilkan planlet tertinggi $(12,10 \pm 0,31$ $\mathrm{cm}$ ) dan planlet tersebut proporsional untuk dipindahkan ke luar botol (Tabel 2).

Planlet yang belum proporsional, dipindahkan (transplant) kembali ke media yang mengandung 0,1 mg/l BA
+ 0,1 mg/l kinetin + 0,5 mg/l NAA dan MS tanpa ZPT. Hasil pengamatan pada tahap ini, menunjukkan bahwa media MS tanpa zat pengatur tumbuh dapat menghasilkan planlet yang proporsional untuk diaklimatisasikan dan relatif tidak berbeda dengan planlet yang dikulturkan dalam media MS yang mengandung ZPT sitokinin dan auksin.

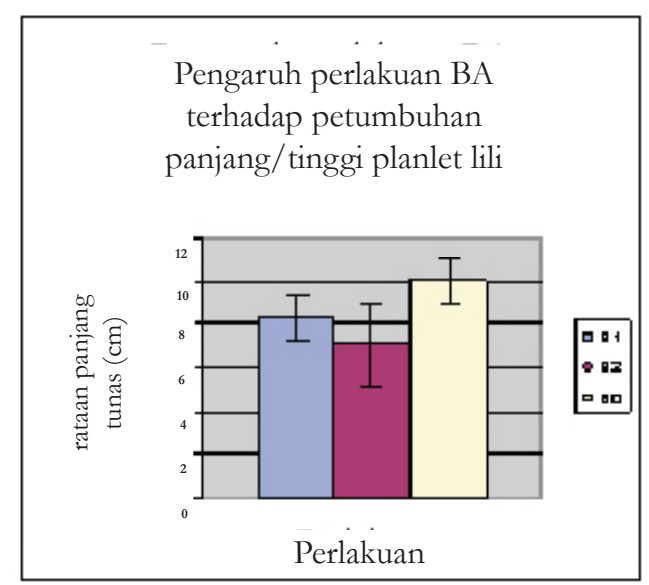

Gambar 6. Histogram Pengaruh BA terhadap pertumbuhan planlet lili

Pengamatan setelah 6 minggu dari subkultur ketiga, tampak kultur memberikan respon positif terhadap perlakuan sitokinin (BA) dan auksin (NAA) (Tabel 2 dan gambar $6,7)$ dalam mendorong pembentukan dan pembesaran planlet. Hal tersebut juga terjadi pada kultur $L$. hansonii, perlakuan $0.01 \mathrm{mg} / \mathrm{l} \mathrm{BA}+0.1 \mathrm{mg} / \mathrm{l} \mathrm{NAA}$ berhasil membentuk bulblet dengan nilai rataan $3,4^{16)}$. Pengaruh positif sitokinin terhadap pembentukan tunas terjadi pula pada kulivar lili Avignon dalam media MS + BA $1 \mathrm{mg} / \mathrm{l}+$ Thidiazuron. Sitokinin (BA dan thidiazuron) mendorong aktifitas sel dan jaringan eksplan sisik umbi lili. Perlakuan penambahan kombinasi BA dan NAA dalam media MS, sering digunakan oleh peneliti untuk budidaya lili secara in vitro: Inisiasi tunas paling cepat terjadi pada kultur klon lili dalam media MS yang mengandung $2 \mathrm{mg} / \mathrm{l} \mathrm{BA}+1 \mathrm{mg} / \mathrm{l} \mathrm{NAA}$, yaitu pada hari ke-13 setelah tanam. Media yang paling 
banyak menghasilkan tunas adalah MS + BA 1 mg/l + NAA 2 mg/l. ${ }^{8)}$ Telah dilaporkan pula hasil penelitian mengenai pengaruh NAA dan BAP terhadap multiplikasi tunas aksiler Lilium Iongiflorum Thunb. Eksplan berasal dari tunas aksiler, potongan batang yang mengandung 1 tunas aksiler di tanam pada medium induksi tunas LS (Linsmaier dan Skoog) yang ditambah NAA dan BAP. Setelah 4 minggu dari saat inisiasi, teramati bahwa laju multiplikasi pada subkultur pertama adalah 1,1 tunas/ minggu, subkultur kedua 1,6 tunas/minggu, dan subkultur ketiga 2,7 tunas /minggu ${ }^{17)}$. Media dasar Murashige dan Skoog (MS) digunakan pula untuk kultur eksplan sisik umbi sejumlah kultivar lili asli Korea. Hasil penelitian tersebut menunjukkan bahwa kemampuan beregenerasi eksplan yang berasal dari bagian tengah umbi, lebih tinggi dibandingkan dengan bagian luar dan dalam umbi. Bagian sisik terbawah (basal) menunjukkan hasil yang terbaik, sementara organogenesis dan pembentukan bulblet meningkat pada bagian distal sisik umbi dengan perlakuan 0,01 ppm NAA dan 0,01 ppm BA. ${ }^{18)}$.

Penelitian teknik kultur jaringan lainnya yang telah dilaporkan adalah untuk perbanyakan sisik umbi Lilium auratum Lindl. dan L. speciosum Thunb., dari eksplan tersebut berhasil berdiferensiasi menghasilkan bakal umbi (bulblets) dan akar. Eksplan sisik umbi tersebut merupakan bahan eksplan terbaik untuk menghasilkan bulblet. Suhu optimum untuk penyimpanan kultur adalah $20^{\circ} \mathrm{C}$ dan $\mathrm{pH}$ optimum 6. Sementara pencahayaan tidak berpengaruh terhadap pembentukan tunas, tetapi dapat menstimulasi pembentukan daun.

Perlakuan penambahan kinetin dalam jumlah relatif tinggi dilaporkan dapat menstimulasi pembentukan tunas dari sisik umbi Lilium. Kandungan NAA dalam media yang relatif tinggi berhasil menginduksi pembentukan akar. Tetapi di lain fihak, kinetin dapat menghambat efek NAA pada pembentukan akar. Kadar $10 \mathrm{~g} / \mathrm{l}$ - $90 \mathrm{~g} / \mathrm{l}$ sukrosa dapat menstimulasi pembentukan organ dan pembentukan bulblet secara konstan. Peningkatan konsentrasi sukrosa dalam medium Murashige-Skoog (MS) berhasil mendorong pembentukan dan pertumbuhan bulblet, tetapi media tersebut menghambat pemanjangan akar. Interaksi perlakuan penambahan konsentrasi medium MS dengan kadar sukrosa yang relatif lebih tinggi dari konsentrasi normal yaitu 90-120 g/l dapat menginduksi pembentukan kalus, tetapi menghambat pembentukan bulblet. Pembentukan bulblet terjadi dalam selang waktu 100 hari dan pembentukan akar 50 hari setelah penanaman'6).

Respon positif eksplan sisik umbi Lilium testaceum terhadap perlakuan sitokinin (kinetin) dan auksin (NAA) juga dilaporkan, bahwa kultur dalam media yang mengandung kedua ZPT tersebut berhasil membentuk bulblet dan kalus secara in vitro dari kultur dalam media MS + 0.1 mg/l NAA $+0,1 \mathrm{mg} / \mathrm{l}$ kinetin. Dari umbi yang dihasilkan secara in vitro tersebut mengandung ß-1,4glucomannans (mannosa: glukosa $=7: 3$; berat molekul $=200 \mathrm{kd}$ ); nilai tersebut strukturnya sama dengan glucomannans yang dihasilkan dari umbi yang tumbuhkan secara in vivo. Media yang mengandung $1 \mathrm{mg} / \mathrm{l}$ NAA berhasil meningkatkan pembentukan kalus, sementara kultur kalus pada media cair hanya menghasilkan sedikit kandungan glucomannans ${ }^{2)}$. Induksi pembentukan tunas, akar dan kalus dengan penambahan ZPT auksin dan peningkatan sukrosa ke dalam media telah berhasil terhadap kultur biji Lilium michiganense. Pengaruh positif auksin dan sitokinin lainnya terhadap pembentukan bulblet kultur lili juga telah dilaporkan dan media tersebut berhasil menginduksi pembentukan bulblet pada kultur in vitro Lilium japonicum Thunb., yaitu jenis lili asli dari daerah Chubu (Jepang), berhasil membentuk 0,7-2,8 bulblet per eksplan setelah 2 bulan dari saat inisiasi dalam media MS yang ditambah 0.1-1.0 $\mathrm{mg} / \mathrm{I} \mathrm{IAA}$. 
Perlakuan kombinasi antara sitokinin (BA) dan auksin (2,4-D) lainnya teramati pada kultur eksplan floret Lilium speciosum Thunb. var. gloriosoides Baker, berhasil membentuk kalus yang dapat berorganogenesis dalam media MS yang ditambah $3 \mathrm{mg} / \mathrm{l}$ 2,4 D and 0,25 mg/l BA.

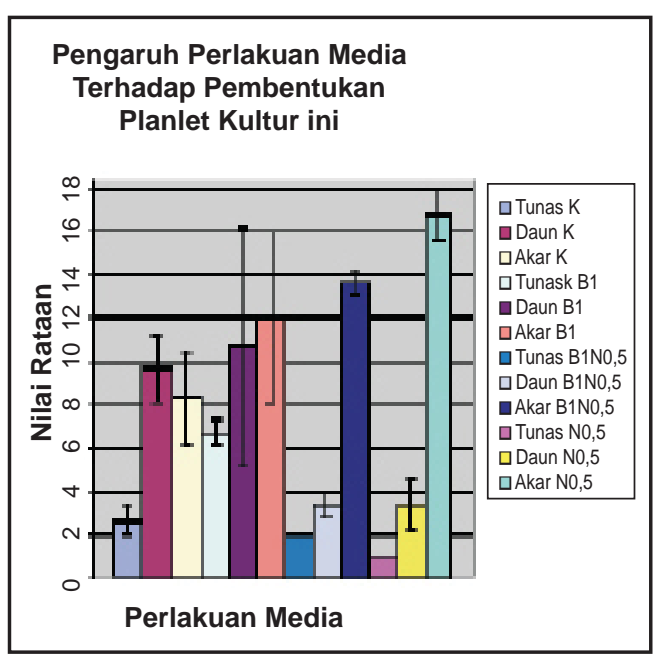

Gambar 6. Pengaruh perlakuan terhadap pada tahap pembesaran dalam interval waktu 3 bulan. Sehingga selama 9 bulan dihasilkan 6000 tanaman. Tanaman berhasil berbunga setelah dua tahun dari saat aklimatisasi ${ }^{19}$.

Pada tahap pembesaran, tunas yang belum menghasilkan akar dikulturkan pada media MS yang mengandung 0,1 mg.I

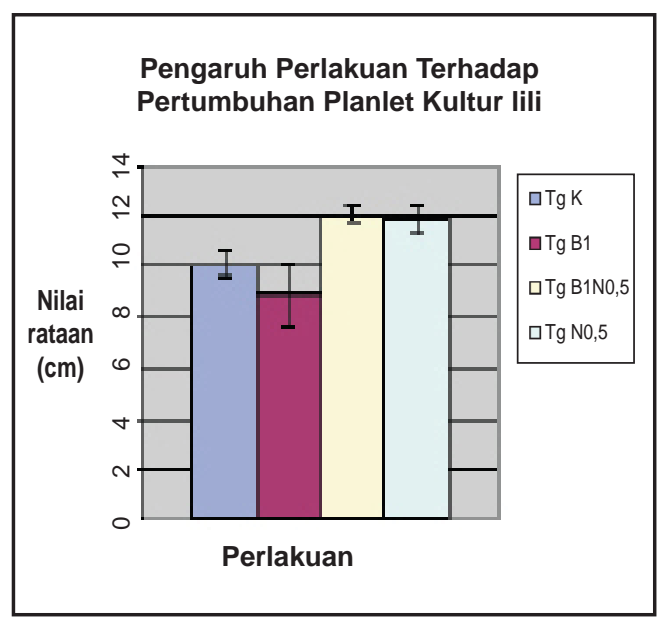

Gambar 7. Pengaruh perlakuan terhadap pertumbuhan planlet pada tahap pembesaran

Tabel 2. Pengaruh perlakuan terhadap pembentukan dan pertumbuhan planlet lili pada tahap pembesaran

\begin{tabular}{|c|c|c|c|c|}
\hline $\begin{array}{c}\text { Perlakuan } \\
\text { BA (mg/l) }\end{array}$ & $\begin{array}{c}\text { Rataan jumlah } \\
\text { tunas }\end{array}$ & $\begin{array}{c}\text { Rataan jumlah } \\
\text { daun }\end{array}$ & $\begin{array}{c}\text { Rataan jumlah } \\
\text { akar }\end{array}$ & $\begin{array}{c}\text { Rataan } \\
\text { panjang tunas } \\
(\mathrm{cm})\end{array}$ \\
\hline $\mathrm{B} 0(\mathrm{~K})$ & $2,67 \pm 0,67$ & $9,67 \pm 1,53$ & $8,33 \pm 2,08$ & $10,10 \pm 0,56$ \\
\hline $\mathrm{B} 1$ & $6,67 \pm 0,57$ & $10,67 \pm 5,51$ & $12,00 \pm 4,00$ & $8,93 \pm 1,30$ \\
\hline $\mathrm{B} 1 \mathrm{~N} 0,5$ & $2,00 \pm 0,00$ & $3,33 \pm 1,15$ & $13,67 \pm 6,06$ & $12,10 \pm 0,31$ \\
\hline $\mathrm{N} 0,5$ & $1,00 \pm 0,00$ & $3,33 \pm 1,15$ & $16,67 \pm 1,15$ & $11,87 \pm 0,61$ \\
\hline
\end{tabular}

Keterangan : Nilai yang tercantum dalam tabel di atas merupakan nilai rataan \pm standar deviasi dan yang ditulis dengan huruf tebal, merupakan nilai tertinggi

Kalus tersebut berhasil membentuk bulblet, sementara planlet terbentuk dalam media MS yang mengandung $0,1 \mathrm{mg} / \mathrm{l} \mathrm{NAA}$ $1 \mathrm{~g} / \mathrm{l}$ arang aktif dan170 $\mathrm{mg} / \mathrm{l} \mathrm{NaH} \mathrm{PO}_{4}$. Lili langka tersebut diperbanyak dari sisik bulblet, dengan tingkat multiplikasi 8 kali kinetin + 0,1 mg/l BA + $1 \mathrm{mg} / \mathrm{l} \mathrm{NAA} \mathrm{(Foto}$ 4). Planlet yang proporsional terbentuk pada media tersebut. Perakaran tunas dapat diinduksi secara in vitro teramati pula pada kultur lili dalam medium LS dengan penambahan NAA. ${ }^{17)}$. 
Aklimatisasi. Pemeliharaan secara ex vitro dilakukan di rumah kaca, planlet (tanaman lengkap) yang telah berukuran 10-15 cm, jumlah akar 6-8, jumlah daun 5-6 ditanam dalam media pasir, tanah dan kompos dengan perbandingan $1: 1: 2$ dan dijaga kelembabannya. Setelah 10 minggu dari saat pemeliharaan secara ex vitro/di luar botol, planlets tersebut telah tumbuh dengan tinggi tanaman telah mencapai 19-22 cm, jumlah daun 6-8 dan akar 15-17. Delapan puluh lima persen tanaman bertahan hidup dan berhasil tumbuh dengan baik.

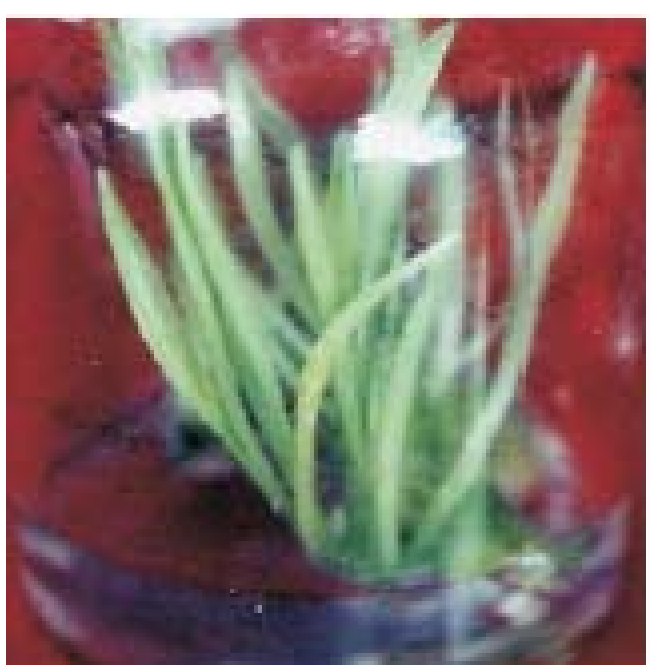

Foto 4. Tahap pembesaran lili

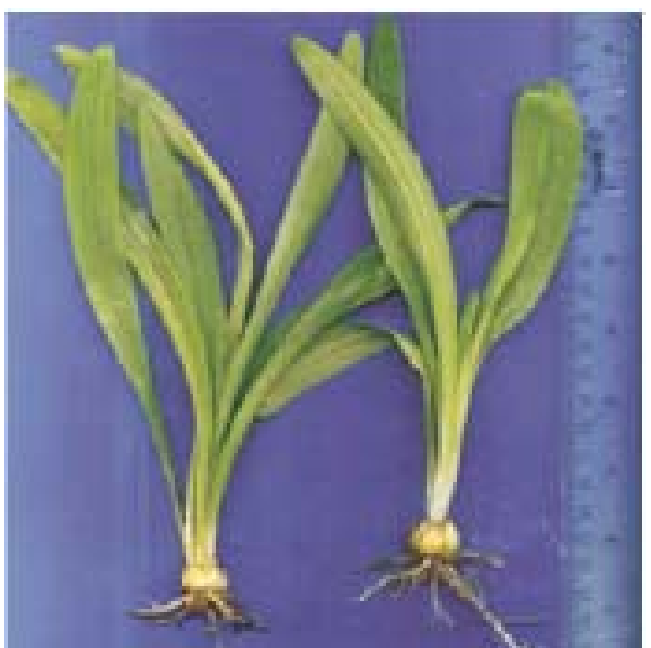

Foto 5. Planlet Lilium sp. pada tahap aklimatisasi

\section{KESIMPULAN}

Perbanyakan lili umumnya dilakukan secara vegetatif dengan sisik umbi secara in vitro dan ex vitro. Perlakuan zat pengatur tumbuh tanaman sangat berpengaruh terhadap pembentukan tunas dan bulbletsisi umbi lili secara in vitro dan ex vitro. Asam giberelat $\left(\mathrm{GA}_{3}\right)$ berhasil mempercepat pembentukan bakal tunas secara ex vitro dan in vitro. Formulasi media yang berhasil mempercepat pembentukan tunas secara in vitro dengan penambahan ZPT, asam giberelat $\left(\mathrm{GA}_{3}\right)$, sitokinin (BA) dan auksin (NAA) telah dikuasai. Melalui teknik in vitro telah berhasil memperbanyak tanaman secara cepat dan massal untuk pembudidayaan dan pemuliaan lili.

\section{DAFTAR PUSTAKA}

1. http://www.floridata.com/ref/L/lili hyb. cfm ; Generated 06 April 2008.

2. Wozniewski .T; W. Blaschek and G. Franz, 1991. In vitro propagation of Lilium testaceum and structural investigation of the storage $ß-1,4$ glucomannan. Plant Cell Reports Volume 10 (9), 457-460.

3. http://www.republika.co.id Generated 13 Maret 2009

4. Hoesen, DSH dan D. Gandawidjaja, 1985. Lili bunga pegunungan. Buletin Kebun Raya 6(6): 141-147

5. Hartmann, HT.; DE. Kester; FT. Davies Jr and RL. Geneve, 1997. Plant Propagation: Principles and Practices, Sixth edition. Prentice Hall New Jersey. 770 pages + XI

6. Takayama, S and M. Misawa, 1979. Differentiation in Lilium bulbscales grown in vitro. Effect of various cultural condition. Plant Physiology 46: 184190. 
7. Winarsih, S, Priyono dan Zaenudin, 1998. Pengaruh zat pengatur tumbuh terhadap perbanyakan kerk lili secara in vitro. Jurnal Hortikultura 8(3): 11451152.

8. http://suhudoedin.blogspot. com/2008/08/kultur-jaringan-lyly.html, Generated 20 Februari 2009

9. Sanjaya, L dan B. Marwoto, 2007. Lili tropis dalam negeri lebih unggul dibanding impor. Sinar Tani edisi 2127 Maret 2007.

10. http://www.liliumbreeding. $\mathrm{nl} /$ breedingresstaff.html Generated 16 Februari 2009

11. Priyono dan A. Susilo, 2002. Respons regenerasi in vitro eksplan sisik mikro kerk lily (Lilium longiflorum) terhadap Ethyl Methane Sulfonate (EMS). Jurnal Ilmu Dasar 3(2): 74-79.

12. Gunta, J.; D. Megre and G. Levinsh. 2006. Effect of cultivation conditions on morphological and biochemical characteristics of lily explants in vitro. Acta Universitatis Latviensis vol. 710, Biology, 29-40.http:priede. bf.lu./v/grozs/LU/LU Bio raksti/ LUBioRaksti/2006/jacobsone.pdf Generated 17 Juli 2007.

13. Matsui, E and JM. Van Tuyl. 1986. Early scale propagation results in forcible bulbs of 'Easter lily'. HortScience vol 21, 1006-1007
14. Tan Nhut, D. 2003. The control of in vitro direct main stem formation of Lilium longiflorum derived from receptacle culture, and rapid propagation by using in vitro stem nodes. Plant growth regulation vol. 40 (2), 179-184.

15. Hoesen, DSH, 2003b. Perbanyakan Amaryllis sp. (AMARYLLIDACEAE) secara in vitro. Gakuryoku Vol. IX(2), 159-163.

16. DaeHoe, G; Y. ByeongWoo and H. BongHee, 2004. In vitro propagation and enlargement of Lilium hansonii Korean Journal of Horticultural Science \& amp; Technology, vol. 22(4), 473476. http://www.cababstractsplus. org/google/abstract. Generated 15 Desember 2008

17. Armelia, M., 2004. Mikropropagasi Lilium Longiflorum Thunb. Melalui multiplikasi tunas aksiler batang (Undergraduate Theses) Departemen Biologi ITB. http://digilib.bi.itb.ac.id/ go.php?id=jbptitbbi-gdl-s1-1994mariaarmel-800 Generated 15 Juni 2007

18. http://www.actahort.org/members/ showpdf?booknrarnr=414 2 Generated 16 Februari 2009.

19. Chang, C; Chen Chang ${ }^{1}$, C. Chen, Y, Tsai, W. Chang, 2000. A tissue culture protocol for propagation of a rare plant, Lilium speciosum Thunb. var. 